\title{
$\mathrm{Bi}$ 添加 $\mathrm{LaMnO}_{3}$ の XPS 分析と磁性 ${ }^{\dagger}$
}

\author{
小川 卓・進藤春雄・竹内宏昌・小泉義晴 \\ 東海大学大学院工学研究科 齿 259-1292 神奈川県平塚市北金目 1117 \\ （2006 年 2 月 22 日受付；2006 年 5 月 9 日掲載決定）

\section{X-ray Photoemission Spectroscopy and Magnetic Properties of Bi Doped $\mathrm{LaMnO}_{3}$}

\author{
Takashi Ogawa, Haruo ShIndo, Hiromasa TAKEUCHI and Yoshiharu KoIzUMI \\ Graduate School of Engineering, Tokai University \\ 1117 Kita-kaname, Hiratsuka, Kanagawa 259-1292
}

(Received February 22, 2006 ; Accepted May 9, 2006)

\begin{abstract}
Perovskite-type $\mathrm{La}_{1}-\mathrm{xBixMnO}$ ( $\mathrm{LBMO}$ ), which are prepared by doping the Bismuth (Bi) ion in $\mathrm{LaMnO}_{3}$, were shown to exhibit the colossal magnetoresistance (CMR) effect. Samples were produced using a sintering process in an air atmosphere as a function of the Bi composition ratio $\mathrm{x}$. X-ray diffraction measurements showed that the LBMO crystal structure varied among an orthorhombic (or rhombohedral) type with $0.0<\mathrm{x}<0.3$, to a cubic type with $0.3<\mathrm{x}<0.5$, and to a monoclinic type with for $0.5<\mathrm{x}$. The CMR effect of LBMO for $\mathrm{x}=0.2$ was approximately $400 \%$ at $140 \mathrm{~K}$. In addition, the magnetoresistance of the LBMO system was found to be proportional to the square of the magnetization. It was interpreted that, from XPS analysis, the valence states of manganese and bismuth atoms in LBMO contain $\left[\mathrm{Mn}^{3+}, \mathrm{Mn}^{4+}\right]$ and $\left[\mathrm{Bi}^{3+}\right.$, $\mathrm{Bi}^{2+}$ (or pseudo-divalent Bismuth)] ionic states.
\end{abstract}

\section{1. は じめに}

$\mathrm{LaMnO}_{3}$ を母材として，2 価のアルカリ土類金属イオ ン E（=Ca, Sr など）を添加したペロブスカイト型 $\mathrm{Mn}$ 酸化物 $\mathrm{La}_{1}-\mathrm{xExMnO}$ （LCMO, LSMO と略記する）は 反強磁性絶縁体相から強磁性金属相への転移点 $(\mathrm{x} \sim 0.1)$ 近傍で超巨大磁気抵抗効果 (CMR) が顕著に出現す る1, 2)。これは Mn イオンが強いフント結合に基づいて 大きなスピン分極を有することに起因する3，4)。すなわ ち母材の $\mathrm{La}^{3+}$ イオンの一部を $\mathrm{Sr}^{2+}$ イオンで置換し, $\mathrm{Mn}$ の $\mathrm{e}_{\mathrm{g}}$ 軌道にホールを導入することで $\mathrm{Mn}^{4+}$ が生成され, 組成の価数構成の平衡要件を満たし, $\mathrm{Mn}^{3+}\left(\mathrm{t}_{2 \mathrm{~g}}^{3} \mathrm{e}_{\mathrm{g}}^{1}\right)-\mathrm{Mn}^{4+}$ $\left(\mathrm{t}_{2 \mathrm{~g}} \mathrm{e}_{\mathrm{g}}^{\mathrm{g}}\right)$ の有する磁気モーメントの強磁性規則配列を形成 することによると考えられる5)。このことは Jahn-Teller (J-T)イオン中心 $\mathrm{Mn}^{3+}\left(\mathrm{t}_{2} \mathrm{~g}_{\mathrm{g}}^{3}\right)$ 準位が縮退して $\mathrm{Mn}^{4+}$ $\left(\mathrm{t}_{2 \mathrm{~g}}^{3} \mathrm{eg}_{\mathrm{g}}^{0}\right)$ 状態に移行することを意味している。

ペロブスカイト型 Mn 酸化物の基本的な電気的・磁気

†第 25 回表面科学講演大会（2005 年 11 月 17 日 11月 19 日）にて発表

E-mail: 4aasdool@keyaki.cc.u-tokai.ac.jp
的性質は Mn イオンの局在スピンと伝導電子スピンとの 間に働く強い相互作用で特徵づけられ，特に電気伝導性 および磁気抵抗効果は結晶構造の対称性に伴うJahnTeller（J-T）歪みの緩和とともに ${ }^{6)}, \mathrm{Mn}^{3+}{ }_{-} \mathrm{Mn}^{4+}$ 二重交 換相互作用で説明される7)。以上のことからペロブスカ イト型 Mn 酸化物の電気的磁気的特性は Mn イオンによ り与えられ，その誘発要素は母材 $\mathrm{LaMnO}_{3}$ の $\mathrm{La}$ 原子の 一部を置換する物質が担っていると考えられる。

$\mathrm{LaMnO}_{3}$ は反強磁性絶縁体 ${ }^{8)}, \mathrm{BiMnO}_{3}$ は強誘電性お よび $\mathrm{T}<103 \mathrm{~K}$ で強磁性を示す “multiferroics”として注 目されている9，10)，これら両者間の La と Bi 組成比によ る構造と電気的磁気的特性の関係については明らかでな い。

ペロブスカイト型 Mn 酸化物強磁性の発現機構には, $\mathrm{Mn}^{3+}-\mathrm{Mn}^{4+}$ 対を基本に, 価電子の平衡状態を満たす組 成構成が必要である. そのためには，(i) 上述のように $\mathrm{LaMnO}_{3}$ の $\mathrm{La}^{3+}$ イオンの一部を, 2 価のアルカリ土類金 属イオン等で置換した $\mathrm{La}_{1}-\mathrm{xExMnO} 3$ 構成をとる，（ii） $\mathrm{La}^{3+}$ イオンの一部をメタロイド金属イオン（Z）等で置 換した $\mathrm{La}_{1}-\mathrm{xZxMnO}$ 構成をとる方法が考えられる。(ii) 
の場合, $\mathrm{Mn}^{3+}-\mathrm{Mn}^{4+}$ 対を形成し，かつ価数の平衡状態 を満たすには, Z Z Z $\mathrm{Z}^{3+}$ インおよび $\mathrm{Z}^{2+}$ イン（もし くは擬似的な $\mathrm{Z}^{2+}$ イオン; 本論文では基イオン $\mathrm{Z}^{3+}$ の一 部が電荷の捕獲などにより $\mathrm{Z}^{2+}$ に変化し, 基イオン $\mathrm{Z}^{3+}$ と $\mathrm{Z}^{2+}$ が共存している場合, 後者を擬似的イオンと呼ぶ） の存在が必要である。

$\mathrm{Bi}\left(6 \mathrm{~s}^{2} 6 \mathrm{p}^{3}\right)$ は 3 価と 5 価以外に 2 価の安定したイオン 化合物をつくることが知られており ${ }^{11 \sim 13)}, \mathrm{LaMnO}_{3}$ を 母材とし La イオンの一部を Bi イオンで置換することで 新規な磁性材料が期待できる。 $\mathrm{LaMnO}_{3}$ を母材に $\mathrm{Bi}$ 添 加して, Laイオンの一部を Bi イオン原子で置換した $\mathrm{La}_{1}-\mathrm{xBixMnO}{ }_{3}(\mathrm{LBMO})$ の場合 ${ }^{14)}, \mathrm{Bi}$ イオン半径(1.70 ̊) は Laイオン $(1.88 \AA) や \mathrm{Sr}$ イオン $(2.15 \AA)$ と比べて小さ いため ${ }^{15)}$, イオン半径の不均衡による格子変形とともに 電荷摇らぎを生じるものと予測される16)。これらのこと から $\mathrm{LaMnO}_{3}$ 格子系の $\mathrm{Mn}$ イオンの価電子および電子状 態は Bi を添加することで強い影響を受けるものと考え られる。そのため LBMO は $\mathrm{Mn}^{3+}-\mathrm{Mn}^{4+}$ イオン状態にお ける電荷移動と二重交換相互作用を基本とする絶縁体相 (反強磁性相)-金属相（強磁性相）の転移が期待される。

これまでの報告によると, $\mathrm{BiMnO}_{3}$ には高加圧成型が 必要であり ${ }^{10)}$, LBMO においても大きな磁気抵抗の発 現には高加圧成型工程が重要であり ${ }^{17)}$, 実際, 加圧成型 を行った $\mathrm{Bi}$ 添加 $\mathrm{LaMnO}_{3}$ 系での電気伝導特性および磁 気抵抗について実験的に検証がなされている14)。

このような背景のもとで $\mathrm{Bi}$ 添加した $\mathrm{LaMnO}_{3}$ の LBMO 系結晶状態および各イオンの価電子状態を調べ ることは, LBMO 系の電気的・磁気的特性, すなわち 電気抵抗率, 磁化特性および磁気抵抗効果の発現機構を 明らかにする上で重要である。

そこで本研究では LBMO 系の各成分元素のイオン状 態をXPS スペクトルの観点から検討を行った。その結 果, LBMO 系における結晶構造は, Bi 組成比 $\mathrm{x}$ に対し て構造転移を起こす。加えて LBMO 系の磁気抵抗は磁 化の自乗に比例することから，二重交換相互作用に従う こと, そして $\mathrm{Mn}$ および $\mathrm{Bi}$ 原子の原子価状態は, $\mathrm{Mn}^{3+}$, $\mathrm{Mn}^{4+}$ および $\mathrm{Bi}^{3+}, \mathrm{Bi}^{2+}$ イオン（もしくは擬似的な $\mathrm{Bi}^{2+}$ イオン）状態であることが確認された。

\section{2. 実 験 方 法}

本実験に用いた $\mathrm{La}_{1}-\mathrm{xBixMnO}$ (LBMO) 試料は以下の 方法で作製した焼結体である。出発原料は純度 $99.9 \%$ の粉末状の $\mathrm{La}_{2} \mathrm{O}_{3}, \mathrm{Bi}_{2} \mathrm{O}_{3}$ および $\mathrm{Mn}_{2} \mathrm{O}_{3}$ であり, それら をそれぞれ所望の比率になるように秤量して混合して均 一によく混成した後, $\mathrm{SiC}$ 発熱体電気炉を用いて大気中 $800^{\circ} \mathrm{C}$ で 4 時間仮焼成した。仮焼成した試料は自然冷却
後, 試料を取り出して粉砕した。これを直径 $8.5 \mathrm{~mm}$ 厚 さ $1.5 \mathrm{~mm}$ の円板状に圧力 $1,000 \mathrm{~kg} / \mathrm{cm}^{2}$ で加圧成型加工 して, 大気中 $1,000{ }^{\circ} \mathrm{C} て ゙ 10$ 時間本焼成を行った。ただ し, 昇温勾配は $0.1{ }^{\circ} \mathrm{C} / \mathrm{s}$, 降温勾配は $0.01{ }^{\circ} \mathrm{C} / \mathrm{s}$ とした。 作製した試料は，結晶構造を X 線回折法 (XRD; X 線 $\mathrm{CuK} \alpha_{1}$; 波長 $\left.1.542 \AA\right)$ ，各イオンの結合状態および組成 比を $X$ 線光電子分光法 (XPS), 電気伝導および磁気抵 抗測定には直流四端子法, 磁気特性を振動試料型磁力計 （VSM）等で測定した。

\section{3. 実験結果および考察}

\section{3. $1 \mathrm{La} 1-\mathrm{xBixMnO}_{3}$ 構造の $\mathrm{Bi}$ 組成比依存性}

$\mathrm{LaMnO}_{3}$ ペロブスカイト型結晶は室温以下で立方晶か ら菱面体もしくは斜方晶へ J-T 歪みを起こしている2)。 これは結晶中の 6 個の酸素イオンによって囲まれた八面 体中心位置の $\mathrm{Mn}^{3+}$ イオン $\left(\mathrm{J}-\mathrm{TMn}^{3+}\right.$ イオン) が, $\mathrm{eg}_{\mathrm{g}}$ 軌 道に 1 個の電子をもち, J-T 歪みによってその軌道の縮 退を解くことに由来する。一方, ゴールドシュミット規 則 $R_{0}+R_{A}=t \sqrt{2}\left(R_{0}+R_{B}\right)$ によると ${ }^{18)}$, 理想的な $\mathrm{ABO}_{3}$ ペロブスカイト型立方格子の構造変形はその変形傾向を 表すパラメータ $\mathrm{t}$ で与えられる。ただし, 各イオンの半 径につき酸素イオン $R_{0}=1.40 \AA$, $\mathrm{A}$ サイト $R_{A}\left(\mathrm{La}^{3+}\right.$ イオ ン $\left.R_{L a}=1.88 \AA\right), \quad \mathrm{B}$ サイト $R_{B}\left(\mathrm{Mn}^{3+}\right.$ イオン $\left.R_{M n}=0.65 \AA\right)$ とする。本実験では A サイトの Laイオンの一部を Bi イオン（Bi ${ }^{3+}$ イオン半径 $R_{B i}=1.70 \AA ）$ で置換するため, $\mathrm{A}$ サイトのイオン半径 $R_{A}$ を $\mathrm{Bi}$ 組成比 $\mathrm{x}$ の関数とし, ゴ ールドシュミット形式にしたがい $R_{x}=x R_{L a}+(1-x) R_{B i}$ とした。ゴールドシュミットの関係式によれば，理想状 態でのペロブスカイト構造は $0.9<t$ のとき立方晶, 0.8 $<t<0.9$ のとき A サイト（4 配位）イオンの格子点を全 て占めることなく斜方晶もしくは菱面体晶へと変形す る。このように格子変形はゴールドシュミットの規則に よると格子を構成するイオンサイズの関数で与えられ る。

そこで, 系の Laイオンの一部をイオン半径の異なる Bi イオンで置換することによる構造変形および J-T 歪 みに及ぼす影響を調べるため XRD 測定を行った。Fig. 1 は LBMO 系の Bi 組成比 $\mathrm{x}$ をパラメータとする室温での XRD 広域プロファイルを示したものである。作製した 試料の一部に $\mathrm{Bi}_{2} \mathrm{O}_{3}$ からの回折線（図中矢印）が認めら れるが，これは試料の作製過程で試料の混成に不均一が あったためと考えられる。また $\mathrm{x}=0.9$ では多くの回折 線が現れているが，これは, $\mathrm{BiMnO}_{3}$ 結晶の作製には高 加圧成型が必要であることを考慮すると ${ }^{17)}$, 良質の結晶 成長に必要な加圧が足りなかったものと考えられる。よ って本実験方法による $\mathrm{Bi}$ 組成比 $\mathrm{x}$ の適応範囲は $0.1<\mathrm{x}$ 


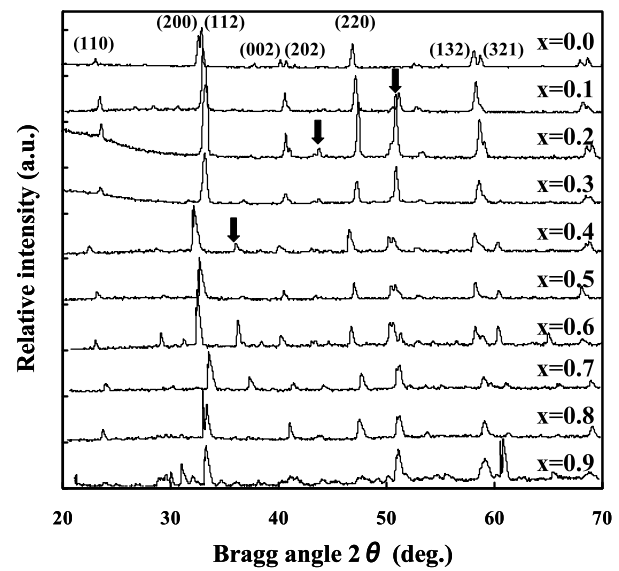

Fig. 1. XRD profiles of LBMO as a function of Bi composition ratio $\mathrm{x}$ (the arrows indicate $\mathrm{Bi}_{2} \mathrm{O}_{3}$ peaks in figure).

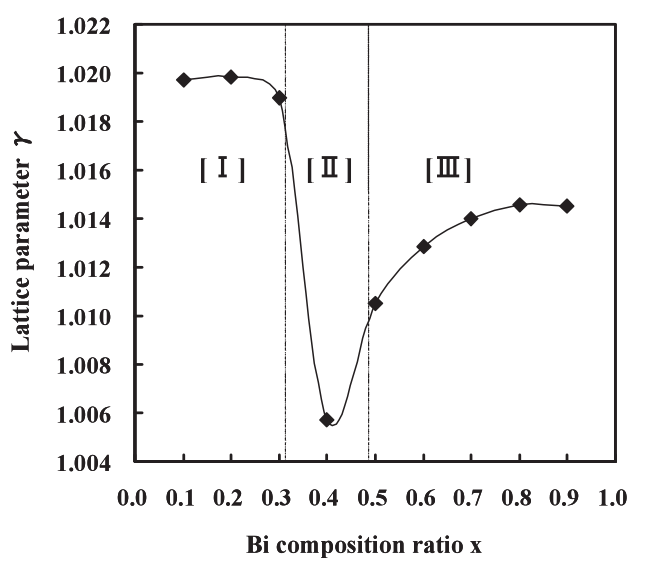

Fig. 2. Lattice parameter $\gamma$ as a function of Bi composition ratio $\mathrm{x}$.

$<0.8$ とした。Fig. 1 の LBMO 回折線に着目すると, 系 の Bi 組成比が $0.0 \leqq \mathrm{x} \leqq 0.3$ のとき, LBMO(112)面から の回折線に顕著なダブレットが認められる。これは理想 的な立方晶から斜方晶（もしくは菱面体晶）に変形した ものであり， J-T 歪効果に起因していると考えられる。 このことはゴールドシュミット規則のパラメータが $t<0.9$ と等価な状態にあることを意味している。しかし, $\mathrm{x}=0.4$ では (112) ダブレット回折線は消えており, J-T 歪みが緩和され結晶の対称性が向上したためと考えられ る。この場合, イオン半径比が 0.9 であることから, 格 子点間隔は $\mathrm{x}$ の増加とともに縮小傾向にあると推察され る。また, 構造的な変形と組成比 $\mathrm{x}$ との関係について, ゴールドシュミット形式によりパラメータ $t$ の值に基づ いて考察すると, 理想的なペロブスカイト立方晶が $t>$ 0.9 であることから, これと等価な条件を作り出すのに 必要な $\mathrm{x}$ 值は 0.47 と見積もられる。しかし, 室温にお ける回折線測定から $\mathrm{x}$ 值を算出すると 0.3 であり, この

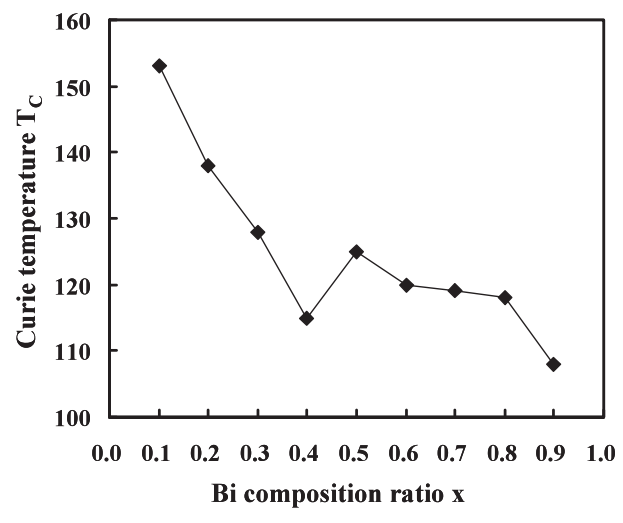

Fig. 3. Curie temperature as a function of Bi composition ratio $\mathrm{x}$.

相違は理想的な構造と実験的な差異によるものと考えら れる。ここで LBMO 系の結晶構造と Bi 組成比 $\mathrm{x}$ の関係 を明確にするため格子パラメータ $\gamma(=c / a)$ と $\mathrm{x}$ の関係 について調べた。Fig. 2 はLBMOの格子パラメータ $\gamma$ の Bi 組成比 $\mathrm{x}$ への依存性を表したものである。 $\gamma$ は, $\mathrm{x}$ $\leqq 0.3$ (領域 $[\mathrm{I}]$ ) でほぼ 1.02 であり, $\mathrm{x}=0.4$ (領域 $[\mathrm{II}]$ ) では極小值 1.005 をとる。これは上述の斜方晶から立方 晶へ転移していることを示唆している。このことは $\gamma$ が $0.4<\mathrm{x}$ (領域 $\left[\mathrm{IIII}\right.$ ) で増大傾向をとり, $\mathrm{BiMnO}_{3}$ 単 斜晶 $(a=3.935 \AA, c=3.989 \AA)$ へ近づいていくことか らわかる9,10)。

\section{$3.2 \mathrm{La}_{1}-\mathrm{xBixMnO} 3$ の磁気特性}

\subsection{LBMO 系の磁気変態点}

LBMO 系の結晶構造と磁性相の関係を調べるため, Bi 組成比 $\mathrm{x}$ をパラメータとする磁気変態点について, VSM の磁気変態点測定プログラムにより測定を行った。 $\mathrm{BiMnO}_{3}$ の磁気変態点は $103 \mathrm{~K}$ であることから9, 10), LBMO 系の磁気変態点も低温であると予測される。 Fig. 3 は LBMO 系キュリー温度 $\mathrm{T}_{\mathrm{C}}$ の $\mathrm{x}$ への依存性を測 定したものである。 $\mathrm{x}=0$ での $\mathrm{LaMnO}_{3}$ は反強磁性であ るので対象外とした。 x が 0.1 のとき強磁性相が出現し, このときの $\mathrm{T} \mathrm{C}$ は $153 \mathrm{~K}$ である。 $\mathrm{T} \mathrm{c}$ は $\mathrm{x}$ の増加とともに 減少傾向を示し, $\mathrm{x}=0.4$ のとき最低点の $115 \mathrm{~K}$ に達した。 その後, $\mathrm{x}$ の増加とともに増大傾向をとり, $\mathrm{x}=0.6$ から 0.8 の間でほぼ $120 \mathrm{~K}$ 一定となり, x がそれ以上で再び 減少傾向を示す。このことは先の XRD 測定における $\mathrm{x}=$ 0.4 での構造転移とこの磁気変態とが相関関係にあるこ とを示唆している。 $\mathrm{LaMnO}_{3}$ に対して $\mathrm{Bi}$ 添加量の少な い段階での TC の急進な増大は, LBMO の La イオンの 一部をイオン半径の小さい $\mathrm{Bi}$ イオンで置換されること で, J-T 歪みが緩和され $\mathrm{Mn}^{3+}(3 \mathrm{~d}-\mathrm{eg})$ 軌道縮退を起こ して, $\mathrm{Mn}^{3+}-\mathrm{Mn}^{4+}$ イオンの磁気モーメントの強磁性配 列を生じ, 反強磁性（絶縁体）相から強磁性（金属）相 
へ転移するためと考えられる。

\subsubsection{LBMO 系の磁化特性}

$\mathrm{LaMnO}_{3}$ の $\mathrm{Bi}$ 添加効果は $\mathrm{J}-\mathrm{T}$ 歪みおよび構造転移を生 じ, 電気抵抗率や磁気転移温度特性に強く影響を及ぼす ことがわかった。そこで, J-T 効果と磁化特性の関係を 調べる目的で, LBMO 系の磁化特性の Bi 組成比への依 存性をVSM により測定した。ただし, 測定温度は, Fig. 3 に示した LBMO 系の Bi 組成比 $\mathrm{x}$ に対するキュリー温

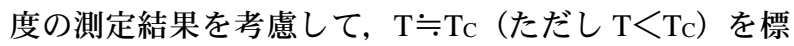
準とした。Fig. 4 は磁化 $\mathrm{M}$ と作用磁場 $\mathrm{H}$ による $\mathrm{M}-\mathrm{H}$ 曲 線から求めた飽和磁化, および分子式当たりの磁気モー メントをボーア磁子数で示したものである。XRD 測定 において x が 0.1 および 0.2 の近傍で J-T 歪みの緩和が 認められ, 飽和磁化の極大点 (約 $66 \mathrm{emu} / \mathrm{g}$ ) が認めら れることから, 磁気モーメントの規則配列が実現してい るものと考えられる。 $\mathrm{x}$ が 0.3 のとき磁化が極小となる のは, この組成比近傍での格子変形により磁気モーメン トの乱れのためと考えられる。ただし, 磁化の極小は構 造の転移組成の值とは必ずしも追随しない。磁化は x が 0.5 以上でほぼ一定であり, $\mathrm{x}$ による顕著な影響は認め られない。これは多量の Bi 添加がなされても格子点の 置換は進まず, Bi 酸化物の析出を余儀なくしているも のと考えられる。実際, $\mathrm{BiMnO}_{3}$ の磁気モーメントの公 表值は $77 \mathrm{~K}$ で $2.3 \mu_{\mathrm{B}}$ であり 9,10$)$, 本実験では $88 \mathrm{~K}$ で $0.25 \mu_{\mathrm{B}}$ であった。この差異は試料作製方法が異なって いること ${ }^{17)}$, および $\mathrm{x}$ が 0.8 以上では LBMO 化合物以 外の $\mathrm{Bi}_{2} \mathrm{O}_{3}$ や XRD 測定に現れていない非磁性酸化物の 生成により, Mn 磁気モーメントが薄められていること を意味している。

\section{3. $3 \mathrm{La}_{1}-\mathrm{xBixMnO}_{3}$ の磁気抵抗効果}

LSMO 系の磁気抵抗（MR）効果は単結晶よりも多結 晶の方が大きく現れることは既に知られている。特に絶 縁相一金属伝導相転移近傍で超巨大磁気抵抗 (CMR) 効

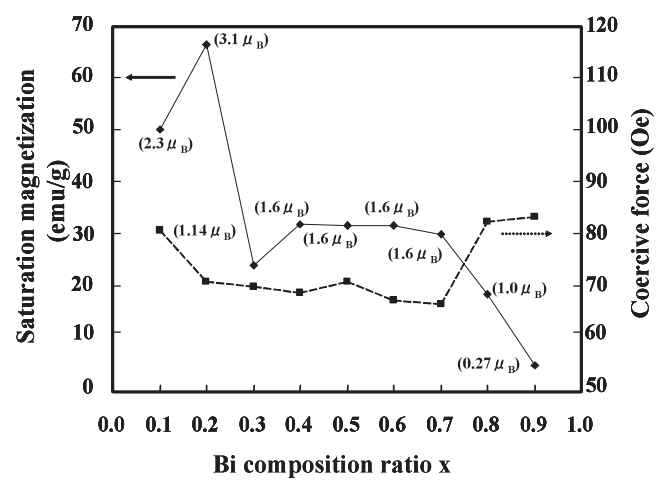

Fig. 4. Saturation magnetization and Coercive force as a function of Bi composition ratio $\mathrm{x}$.
果が発現する。

磁気抵抗比は, $[\rho(H)-\rho(0)] / \rho(0)$ の関係で与えら れ, $\rho(\mathrm{H})$ は強さ $\mathrm{H}[\mathrm{Oe}]$ を印加したときの抵抗率, $\rho(0)$ は磁場の強さゼロのときの抵抗率である。

本実験で作製した LBMO 系結晶の MR 効果の Bi 組成 比 x への依存性を Fig. 5 に示す。測定には直流四端子法 を用い，測定条件は Bi 組成比ごとのキュリー温度を考 慮して $\mathrm{T} \fallingdotseq \mathrm{T}_{\mathrm{C}}$ とし, 印加磁場 $\pm 3 \mathrm{kOe}$, 試料への供給電 流 $5 \mathrm{~mA}$ を標準とした。測定の結果, $\mathrm{x}=0.2$ で極大（約 $400 \%$ ）を示し, $\mathrm{x}=0.4$ で極小（約 $50 \%$ ）となり, $\mathrm{x}=0.5$ 以上でほぼ一定であり顕著な変化は認められなかった。 ここで LBMO 系の磁気抵抗効果について考察する。二 重交換相互作用を起源とする磁気抵抗効果は低磁場域に おいて $\rho(M) / \rho(0)=1-C\left(M / M_{S}\right)^{2}$ の関係で与えられ る3)。ここで M は磁化, Ms は飽和磁化および $\rho(\mathrm{M}), \rho$ (0) は磁化が 0 と M のときの抵抗率, $C$ は磁気抵抗の特 性定数である。この関係式での磁化 $\mathrm{M}$ の範囲としては 磁化の立ち上がり, すなわち初期磁化曲線を用いるので $\mathrm{M} \leqq 0.3 \mathrm{Ms}$ 程度の範囲で設定される。測定温度は磁化の 測定と同じ $\mathrm{T} \fallingdotseq \mathrm{T}_{\mathrm{C}}$ である。この関係式に実験から求め た各值を代入して定数 $C$ が得られる。実際に定数 $C$ を Bi 組成比 $\mathrm{x}(0.2,0.4$ および 0.6) について算出したも のを Fig. 6 に示す。図は結晶構造の変化する $\mathrm{x}=0.2,0.4$ および 0.6 のときの $C$ の值を表している。この図から 各々の $\mathrm{x}$ に対して直線を描き, 上述の関係式を満たして いることが確認できる。したがってこの直線から傾き $C$ を求めると $\mathrm{x}=0.2$ のとき $C=3.81$ となる。同様にして $\mathrm{x}=0.4$ と $\mathrm{x}=0.6$ は $C=1.23, C=1.33$ である。このこと から LBMO 系における磁気抵抗効果は, 磁化 M の自乗 に比例していることから二重交換相互作用によるものと 解釈される。さらに $\mathrm{Bi}$ 組成比 $\mathrm{x}$ に対する定数 $C$ との関 係について Fig. 7 に示す。磁気抵抗の特性定数 $C$ は, Bi

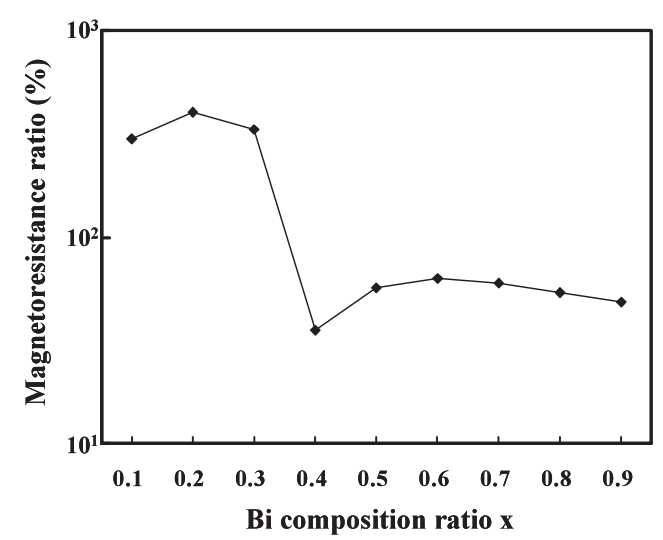

Fig. 5. Magnetoresistance ratio as a function of Bi composition ratio $\mathrm{x}$. 


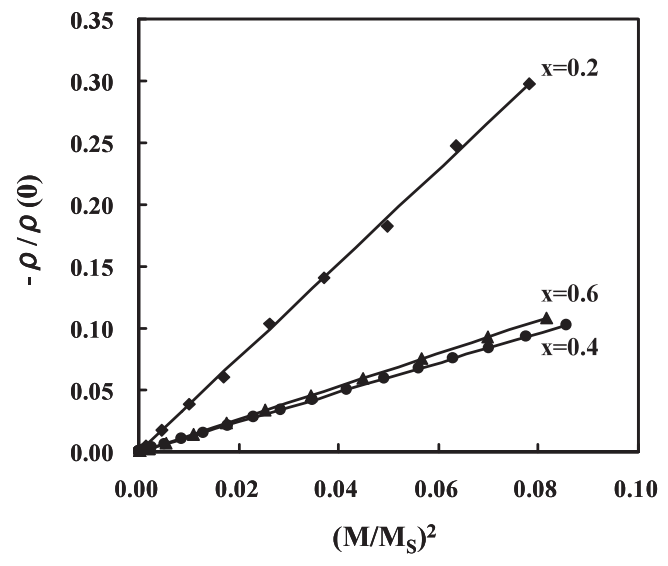

Fig. 6. The relationship between $-\rho / \rho(0)$ and $(\mathrm{M} / \mathrm{Ms})^{2}$ ( $\mathrm{M}$ is area of $\mathrm{M} \leqq 0.3 \mathrm{Ms}$ ).

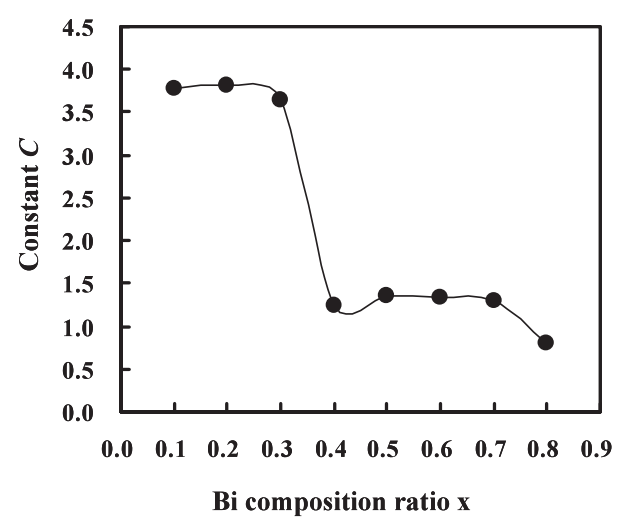

Fig. 7. Constant $C$ as a function of Bi composition ratio x.

組成比 $\mathrm{x}$ が $0.1 \leqq \mathrm{x} \leqq 0.8$ において, 磁気抵抗の実験結果 と同様の傾向を示していることから, LBMO 系の磁気 抵抗効果の発現は二重交換相互作用に起因していると判 断される。しかし $\mathrm{x}=0.9$ の場合, 上述の関係式を用い て $C$ を算出すると磁化 $\mathrm{M}$ の自乗には比例しない。これ は $\mathrm{x}=0.9$ の組成は弱強磁性 $\mathrm{BiMnO}_{3}$ に極めて近いこと から, CMRの発現は得られないものと考えられる。こ のことから LBMO 系において超巨大磁気抵抗効果の発 現のための, 本実験の範囲内において Bi 組成比 $\mathrm{x}$ の適 用範囲は $0.1 \sim 0.8$ である。

\section{$3.4 \mathrm{La} 1-\mathrm{XBiXMnO}_{3}$ の XPS 測定}

XPS において, 放出される電子は, $K E=h v-B E-\phi \mathrm{s}$ で与えられる運動エネルギーを持つ。ここで $h v$ はフォ トンエネルギー, $B E$ は電子が生じる原子軌道の結合エ ネルギーおよび $\phi \mathrm{s}$ は仕事関数である。エネルギー原点 は，フェルミ準位で結合エネルギーがゼロとなる。

作製した試料の組成比の同定および各イオンの価数を 調べる目的でXPS 測定を行った。測定条件として, 使 用装置は Quantum 2006 (アルバックファイ社製), 線源 には $\mathrm{Al}(1260 \mathrm{eV})$ を用い, 試料表面から深さ方向の組

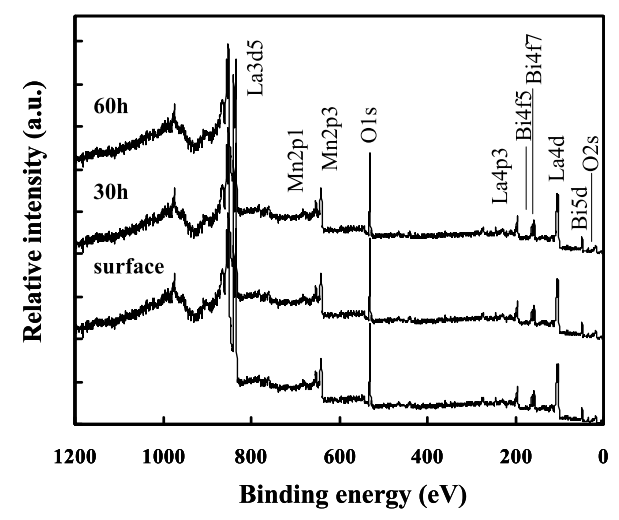

Fig. 8. XPS spectrum profiles of LBMO $(x=0.2)$ for a sample with an untreated surface and samples etched for $30 \mathrm{~h}$ and $60 \mathrm{~h}$.

成濃度分布および単一イオン状態を調べるため, 表面か ら深さ方向を Ar イオンエッチングにより表面, $30 \mathrm{~h}$ お よび 60 h 測定を行った。Fig. 8 はその一例として LBMO $(\mathrm{x}=0.2)$ における XPS 広域プロファイルを示したもの である。測定は, 試料表面および Ar イオンエッチング を $30 \mathrm{~h}$ と $60 \mathrm{~h}$ 行ったものである。それぞれの条件にお ける相対積分強度から算出した組成比のずれは認められ ないことから, 化学量論的組成を満足していると考えら れる。また，試料組成に対するエッチングによる損傷は 測定誤差の範囲内である。同様に他の試料の組成比につ いても測定して確認している。したがって, 本実験に用 いた LBMO 系試料の組成比は $\mathrm{La}_{1}-\mathrm{xBi}_{\mathrm{x}} \mathrm{MnO}_{3}$ の形式で 成り立っていると判断される。

ペロブスカイト型 Mn 酸化物系の電気的磁気的特性 は, $\mathrm{Mn}^{3+}$ と $\mathrm{Mn}^{4+}$ イオンとの二重交換相互作用に基づ く電荷移動に由来するものであり, 添加物の原子価状態 で Mn イオン価数状態が与えられる。伝導性酸化物にお いて, 電荷の供与体から受容体への移動による原子価状 態を調べるのに, XPS 測定は有効な方法である。そこ で母材 $\mathrm{LaMnO}_{3}$ に Bi 添加した LBMO 系における Bi お よび Mn の原子価状態を調べる目的で, $B i\left(4 \mathrm{f}_{5} / 2163 \mathrm{eV}\right.$; $\left.4 \mathrm{f}_{7 / 2} 156 \mathrm{eV}\right), \operatorname{Mn}\left(2 \mathrm{p}_{1 / 2} 652 \mathrm{eV} ; 2 \mathrm{p}_{3 / 2} 641 \mathrm{eV}\right), \quad \operatorname{La}\left(3 \mathrm{~d}_{3 / 2}\right.$ $851.7 \mathrm{eV} ; 3 \mathrm{~d} 5 / 2834.9 \mathrm{eV})$ および O(1 s $530 \mathrm{eV})$ のスペク トルに着目して, 結合エネルギーの化学シフトを測定し た。Fig.9 (a) は $\operatorname{LBMO}(\mathrm{x}=0.2)$ の $\operatorname{Mn}(2 \mathrm{p})$ のPS によ る結合状態および比較のため $\mathrm{MnO}_{2}, \mathrm{Mn}_{2} \mathrm{O}_{3}$ 焼結体試料 の Mnスペクトルである。LBMO の Mn (2 p p $3 / 2)$ と Mn $\left(2 \mathrm{p}_{1 / 2}\right)$ の各スペクトルは幅広いプロファイルを示して いる。この原因として 2 通りの見方ができる。1 つは $\mathrm{Mn}^{3+}$ と $\mathrm{Mn}^{4+}$ の間であることから $\mathrm{Mn}^{3.33+}$ 状態, もう 1 つは $\mathrm{Mn}^{3+}$ と $\mathrm{Mn}^{4+}$ の複合スペクトル状態が考えられる。前 者の場合, 単結合遷移金属の磁性理論では起こりうる 


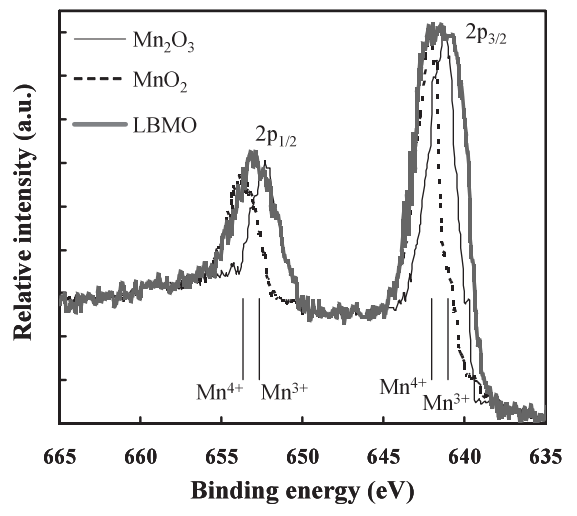

(a) $\left[\mathrm{Mn} 2 \mathrm{p}_{1 / 2}, \mathrm{Mn} 2 \mathrm{p}_{3 / 2}\right]$ of $\mathrm{Mn}_{2} \mathrm{O}_{3}$, $\mathrm{MnO}_{2}$, and $\operatorname{LBMO}(\mathrm{x}=0.2)$

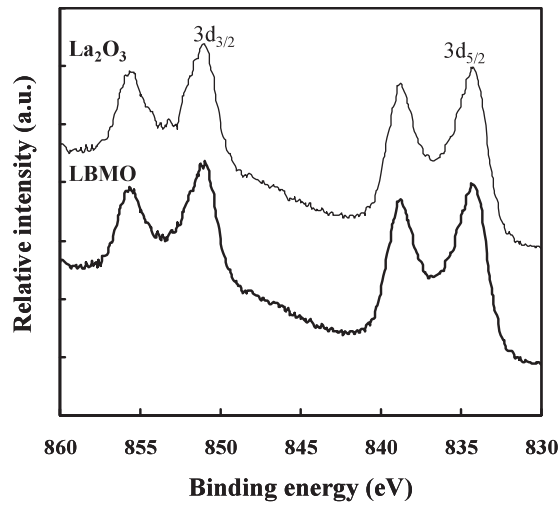

(c) $\left[\mathrm{La} 3 \mathrm{~d}_{3 / 2}, \mathrm{La} 3 \mathrm{~d}_{5 / 2}\right]$ of $\mathrm{La}_{2} \mathrm{O}_{3}$ and $\operatorname{LBMO}(\mathrm{x}=0.2)$

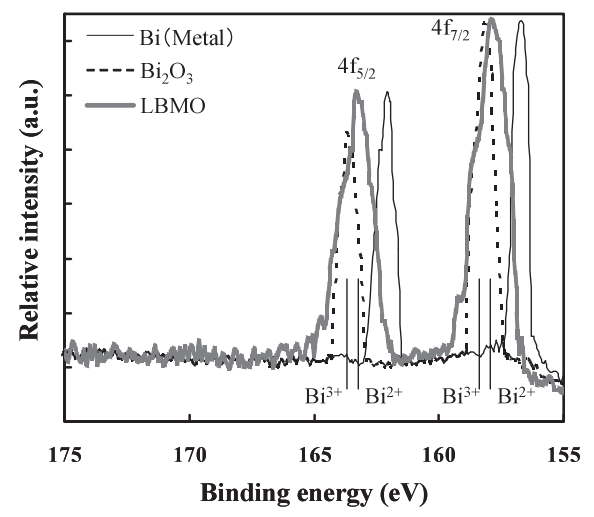

(b) $\left[\mathrm{Bi} 4 \mathrm{f}_{5 / 2}, \mathrm{Bi} 4 \mathrm{f}_{7 / 2}\right]$ of $\mathrm{Bi}$ (metal), $\mathrm{Bi}_{2} \mathrm{O}_{3}$, and LBMO $(x=0.2)$



(d) $\mathrm{O} 1 \mathrm{~s}$ of $\mathrm{LaMnO}_{3}$ and $\operatorname{LBMO}(\mathrm{x}=0.2)$

Fig. 9. XPS spectrum profiles of each element in LBMO $(x=0.2)$.

が19)，イオン結合ではこれまで報告は見られない。一方， 3.3 で LBMO 系の磁気抵抗が磁化の自乗に比例している こと，および J-T イオン中心 $\mathrm{Mn}^{3+}$ のエネルギー準位の 縮退と $\mathrm{Mn}^{4+}$ イオン生成し, これらのイオンによる二重 交換相互作用を基本としていることから, 後者の $\mathrm{Mn}$ $\left[2 \mathrm{p}_{3 / 2} ; \mathrm{Mn}^{3+}(658 \mathrm{eV}), \mathrm{Mn}^{4+}(656 \mathrm{eV})\right]$ および $\mathrm{Mn}$ $\left[2 \mathrm{p}_{1 / 2} ; \mathrm{Mn}^{3+}(654.5 \mathrm{eV}), \mathrm{Mn}^{4+}(652.5 \mathrm{eV})\right]$ の複合スペク トルをなしているものと考えられる。Fig. 9(b) は LBMO $(\mathrm{x}=0.2)$ の Bi (4 f $)$ の XPS スペクトルを示したもので ある。図は比較のため Bi（金属）と焼結法を用いて作 製した $\mathrm{Bi}_{2} \mathrm{O}_{3}$ も一緒に示してある。LBMO の Bi スペク トルは $\mathrm{Bi}_{2} \mathrm{O}_{3}$ のスペクトルと比べ約 1.5 倍の広がりがあ る。これは, 母材である $\mathrm{LaMnO}_{3}$ の $\mathrm{La}$ イオンサイトの 一部を Bi イオンで置換すると, 両イオンのイオン半径 の差異による格子変形および電荷摇らぎから, J-T イオ ン中心 $\mathrm{Mn}^{3+}$ の縮退（J-T 歪み緩和）と $\mathrm{Mn}^{4+}$ イオン生成 に伴い, $\mathrm{Bi}$ 電子軌道の電子受容がなされ, $\mathrm{Bi}^{2+}$ イオン （もしくは擬似的な $\mathrm{Bi}^{2+}$ イオン）状態の生成が考えられ る. そのため $\mathrm{Bi}\left(4 \mathrm{f}_{7 / 2}\right)$ と $\mathrm{Bi}\left(4 \mathrm{f}_{5 / 2}\right)$ の各スペクトルの広
がりは, $\mathrm{Bi}\left[4 \mathrm{f}_{7 / 2} ; \mathrm{Bi}^{3+}(156 \mathrm{eV}), \mathrm{Bi}^{2+}(158 \mathrm{eV})\right]$ よび $\mathrm{Bi}\left[4 \mathrm{f}_{5 / 2} ; \mathrm{Bi}^{3+}(161.5 \mathrm{eV}), \mathrm{Bi}^{2+}(163.5 \mathrm{eV})\right]$ 結 合エネル ギー状態を形成し，それぞれの状態での複合スペクトル をなしているためと推察される。したがって本実験で作 製した LBMO 系酸化物結晶では $\mathrm{Bi}^{3+}$ と $\mathrm{Bi}^{2+}$ （もしくは 擬似的な $\mathrm{Bi}^{2+}$ イオン) 状態を生成しており, $\mathrm{Mn}^{3+}, \mathrm{Mn}^{4+}$ イオン状態と相関関係をもっていると考えられる。 La （3d）スペクトル，O(1s)スペクトルは Fig. 9 (c), Fig. 9 （d）に示すように，それぞれ単一イオン状態 $\left(\mathrm{La}^{3+}\right.$, $\left.\mathrm{O}^{2-}\right)$ を生成しているため鋭いスペクトルが観測されて おり, 混合時に所望した原子価状態を保持している。こ の XPS 測定の範囲内で, $\mathrm{Bi}$ 添加 $\mathrm{LaMnO}_{3}\left(\mathrm{La}_{1}-x \mathrm{Bi}_{x}\right.$ $\left.\mathrm{MnO}_{3}\right)$ は $\mathrm{La}$ 原子の一部を $\mathrm{Bi}$ 原子で置換し, $\mathrm{Bi}^{3+}$ イオ ンおよび $\mathrm{Bi}^{2+}$ イオンの存在の可能性を示唆している。 また Mn イオンは電荷のつり合いから $\mathrm{Mn}^{3+}$ イオンおよ び $\mathrm{Mn}^{4+}$ イオを生成し, LBMO 全体として $\mathrm{La}^{3+}$ $\left(\mathrm{Bi}^{3+} ; \mathrm{Bi}^{2+}\right)\left(\mathrm{Mn}^{3+} ; \mathrm{Mn}^{4+}\right) \mathrm{O}^{2-}$ 価数構成をなしている と推察される。以上のことから LBMO 系における特異 な電気的磁気的特性は, $\mathrm{Mn}^{3+}-\mathrm{Mn}^{4+}$ におけるスピンを 
伴う電荷移動と強い磁気相関に起因しているものと考え られる。

\section{4. ま と め}

本研究は $\mathrm{LaMnO}_{3}$ を母材に $\mathrm{Bi}$ 組成比 $\mathrm{x}$ をパラメータ として添加し, ペロブスカイト型 Mn 酸化物 $\mathrm{La}_{1}-\mathrm{xBix}$ $\mathrm{MnO}_{3}(\mathrm{LBMO} ; 0.1 \leqq \mathrm{x} \leqq 0.9)$ の焼結結晶を作製した。作 製した LBMO の結晶構造, 組成原子の原子価状態, お よび電気的磁気的特性などについて測定した結果, 以下 のことがわかった。

(1) $\mathrm{LaMnO}_{3}$ 母体結晶の $\mathrm{La}$ イオンの一部を $\mathrm{Bi}$ イオン で置換することにより，ゴールドシュミット規則 に基づき J-T 歪みの緩和が確認された。XRD 測 定結果から Bi 組成比 $\mathrm{x}$ が $0.0 \leqq \mathrm{x} \leqq 0.3$ では斜方晶 (もしくは菱面体晶), $0.3<x<0.5$ で立方晶, 0.5 <x では単斜晶を形成している。また本実験方法 による LBMO 結晶の化学量論的組成比の適用で きる範囲は $0.1 \leqq \mathrm{x} \leqq 0.8$ である。

(2) LBMO 系の超巨大磁気抵抗効果は, Bi 組成比 $\mathrm{x}$ が $0.1 \leqq \mathrm{x} \leqq 0.8$ の範囲にあって $\mathrm{T}=140 \mathrm{~K}$ のとき, $\mathrm{x}=0.2$ で最大約 $400 \%$ を得た。この磁気抵抗の 変化は LBMO 系の磁化の自乗に比例（比例定数 $\mathrm{C}=3.81)$ することがわかった。このことから LBMO 系の磁気抵抗効果は, LCMO, LSMO な どと同様に $\mathrm{Mn}^{3+}-\mathrm{Mn}^{4+}$ による二重交換相互作用 に起因しているものと考えられる。

（3）XPS スペクトルから，作製した LBMO 結晶の組 成成分は化学量論的条件を満たしていることがわ かった。また, Mnおよび Bi の XPS スペクトル は大きな広がりを示した。これらスペクトルの広 がりは, J-T イオン $\mathrm{Mn}^{3+}-\mathrm{e}_{\mathrm{g}}$ 軌道の縮退に伴い生 成される $\mathrm{Mn}^{4+}$ イオンと $\mathrm{Mn}^{3+}$ イオンとの共存に よるものである。また $\mathrm{Mn}^{4+}$ イオンの生成過程で 一部 $\mathrm{Bi}^{3+}$ イオンへの電子供与がなされ, $\mathrm{Bi}^{2+}$ 个 オン（あるいは擬似的な $\mathrm{Bi}^{2+}$ イオン）を生成し
$\mathrm{Bi}^{3+}$ イオンとの共存によるものと推察される。こ とから $\left(\mathrm{Bi}^{3+} ; \mathrm{Bi}^{2+}\right),\left(\mathrm{Mn}^{3+} ; \mathrm{Mn}^{4+}\right)$ の複合スペ クトルをなしていると解釈される。その結果, $\mathrm{LBMO}$ の価数構成は $\mathrm{La}^{3+}\left(\mathrm{Bi}^{3+} ; \mathrm{Bi}^{2+}\right)\left(\mathrm{Mn}^{3+}\right.$; $\left.\mathrm{Mn}^{4+}\right) \mathrm{O}^{2-}$ を示唆している。

\section{文献}

1) G.H. Jonker and J.H. Van Santen: Physics 16, 337 (1950), 22 (1956).

2) C.M. Varma: Phy. Mod. Phys. 48, 209 (1976).

3) Y. Tokura, A. Urushibara, Y. Moritomi, T. Arima, A. Asamitsu, G. Kido and N. Furukawa: J. Phys. Soc. Jpn 63, 3931 (1994).

4) 古川信夫 : 固体物理 32, 284 (1997).

5) N.F. Mott: "Metal-Insulator Transitions" (Taylor \& Francis LTD, London, 1974).

6) H.A. Jahn and E. Teller: Proc. Roy. Soc. (London) A 161, 220 (1937).

7) P.W. Anderson and H. Hasegawa: Phys. Rev. 100, 675 (1955).

8) T. Hotta, S. Yunoki, M. Mayr and E. Dagotto: Phy. Rev. B 60, R 15009 (1999).

9) F. Sugawara, S. Iida, Y. Syono and S. Akimoto: J. Phys. Soc. Jpn. 25, 1553 (1968).

10) T. Kimura, S. Kawamoto, I. Yamada, M. Azuma, M. Takano and Y. Tokura: Phy. Rev. B 67, 180401 (R) (2003).

11) 井口洋夫 : “元素と周期律表” (裳華房, 1980).

12) K. Musiol and M. Stanek: Spectrochem. Acta, Part B 38, 1067 (1983).

13) N. Shimomura and K. Ichikawa: Electrochemistry 67, 649 (1999).

14) T. Ogawa, A. Sandhu, M. Chiba, H. Takeuchi and Y. Koizumi: J. Magn. Magn. Mater. 290/291, 933 (2005).

15) R.D. Shannon: Acta Cryatallogr. 32, 751 (1976).

16) C.M. Varma: Rev. Mod. Phys. 48, 219 (1976).

17) K. Gajek, M. Bibes, M. Varela and J. Fontcuberta: J. Appl. Phys. 97, 103909 (2005).

18) V.M. Goldshmidt: Ber. Deut. Chem. Ges. 60, 1270 (1927).

19) L. Pauling: J. Am. Chem. Soc. 69, 542 (1947). 